\title{
SELF-INDULGENCE AND PURCHASING BEHAVIOR TOWARD FAST MOVING CONSUMER GOODS (FMCG) DURING THE INFLATION TIME
}

\author{
Hoàng Thị Phương Thảo, Open University HCMC \\ hthiphuongthao@yahoo.com
}

\begin{abstract}
Inflation is no longer a new thing to Vietnam. Vietnam was in the top ten countries in the world which had the highest inflation rate in 2011 and the threat of inflation always exists till now. Vietnamese consumers, as a result, prepared themselves to cope with the tough economic time. This study's aim is to study the attitude and behavior of Vietnamese consumers when buying FMCG categories during the inflation time. The research classifies whether Vietnamese consumers have any change in purchase behavior during inflation versus a normal economic situation and their future purchase intention in correlation with their perception towards future macro economics' context. The study includes the research on several aspects such as the consumers 'attitude towards economy status, needs of self-indulgence, and the change in consumers' FMCG spending during inflation time as well as their concerns about their future FMCG purchase.
\end{abstract}

Keywords: Inflation time, FMCGs, self-indulgence, purchasing decision.

\section{INTRODUCTION}

After a long fast growing period since "Doi Moi" program in 1986, Vietnam's economy started to show some uncertainties which resulted in high inflation in 2008 - 2009 and 2010 2011. The overall inflation rate reached $23 \%$ in 2008 and $18.6 \%$ in 2011 but fresh food's price grew by $30-40 \%$ while such essential accounted for $60 \%$ of a household's monthly spending. Vietnam was indeed in the top ten countries which had the highest inflation rate in 2011 (CIA World Factbook, 2012). The average salary was improved only by $10-12 \%$ per year, while the inflation rate achieved $18.6 \%$ in 2011 (Nielsen Vietnam, 2011). Vietnamese consumer confidence continuously dropped from 109 index in Quarter 3 of 2009 to 103 in Quarter 4 of 2010 and 99 in Quarter 4 of
2011 and 94 in Quarter 1 of 2012 (Nielsen Vietnam, 2012). The high inflation threat is still there if the essentials prices cannot be controlled. All the Vietnamese households were put under the pressure to cut down on spending or have a better spending allocation.

The consumer price index has been kept at the high level with the peak in 2008 (23\%), slowed down in 2009 and early 2010 but started to pick up in the second half of 2010 till now (Vietnam General Statistics Office, 2012). It's different from the 2008 inflation, while the economic engine of growth was still strong, the end 2010-2011 inflation did have a serious impact on the FMCG purchasing power. The yearly growth rate of FMCG volume consumption (taking an example of six key cities of Ho Chi Minh, Hanoi, Cantho, Nhatrang, 
Danang and Haiphong) was in a sharp slowly recovered at low level up to now decline trend since early 2011, hitting the (see Figure 1).

bottom point by June and July 2011 and

Figure 1. FMCG department growth rate year on year in 6 major cities

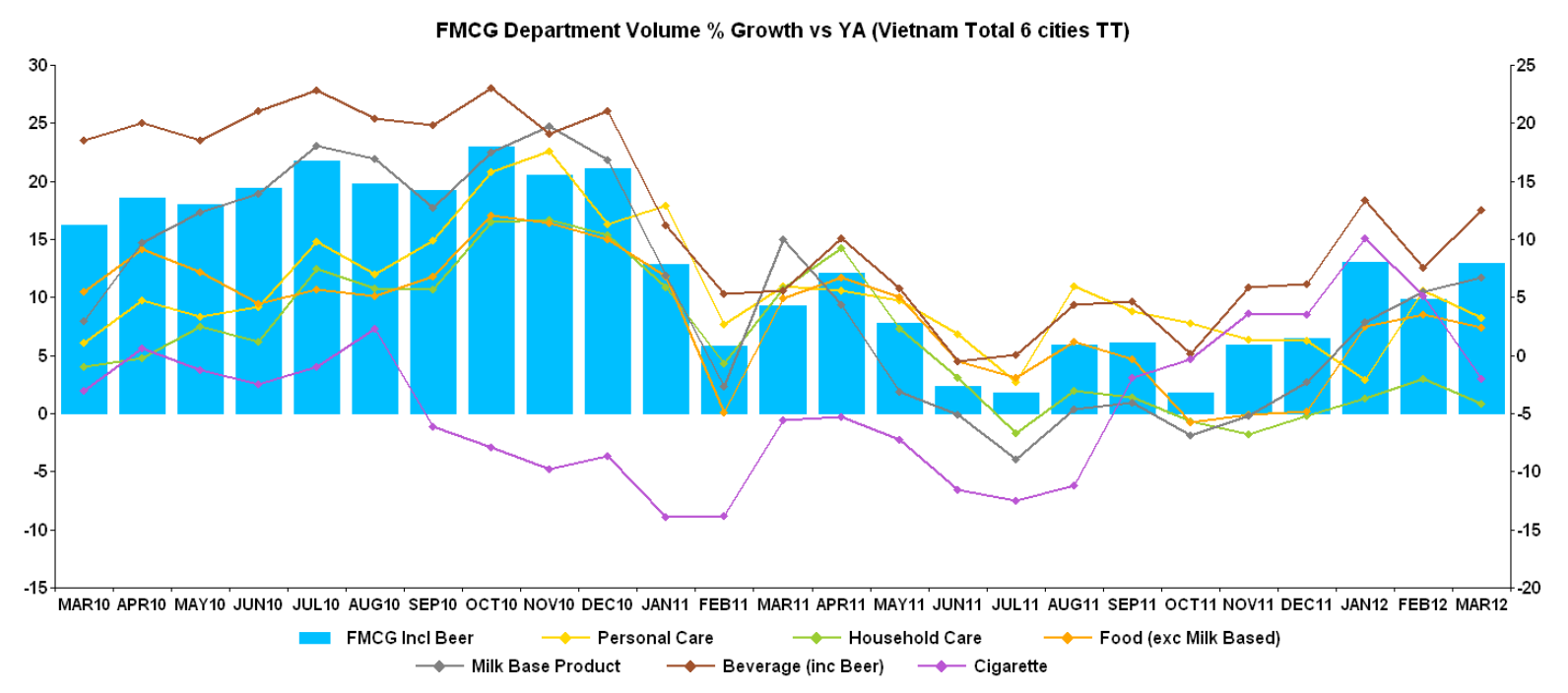

Source: Nielsen Vietnam, 2012

The high inflation rate and low consumer confidence index seriously impacted to the purchase power. More than 79,000 enterprises had to be closed in 2011 and 17,735 is the number in first 4 months of 2012. The stockpile index of processing and manufacturing sector rose by 21.1 percent year on year in January (Vietnam Government Statistics Office, 2012). It is time for all manufacturers to identify and focus on the right portfolio that will sell despite consumers' shrinking budgets.

However, there is still a desire for self-indulgence which make them head to 'affordable premium and/ or selfindulgence products, while Vietnam market trend is getting more and more integrated into the global trend. Consumers are more connected to the world via the development of technology. They have arising need for new experimentation to catch up with what is happening globally. Besides, the increase of middle and high social economic class backs up for the higher self-indulgence demand, especially in main cities like Hanoi and Ho Chi Minh City.

With the above problems, consumer behavior during inflation and recession time is a must understanding for all entrepreneurs if they want to survive and overcome this tough time. The companies must understand clearly the actual and potential reactions of their targeted consumers in terms of what they buy and what can make they buy. Therefore, the purpose of this study is to identify the consumers' reaction towards the FMCG purchase during inflation time. This will also help to validate whether the selfindulgence demand is high in Vietnam market in this time or not. In concrete, the paper will try to answer the following questions:

During the inflation time, whether consumers cut down their spending on what they perceive un-necessaries or not? 
Are consumers more active in seeking for better saving choice such as products on promotion, cheaper brands, smaller package size, etc.?

Along with the getting more sophisticated consumer demand, whether consumers head to affordable premium and/ or self-indulgence products or not?

What is the trend of consumers' FMCGs consumption in the coming year?

These answers will help manufacturers and retailers to understand more about expectations from consumers, values they are caring about and what are going to be the trends in their purchase behavior in order to have a better business plan to survive in the tough economic time and/ or sustain the growth.

\section{Research scope and methodology}

Secondary and primary data are used in the research. Secondary data are collected from text books, journals and websites. The primary data is collected via both qualitative and quantitative approaches. The qualitative research is an exploratory action to get deeply into what, how consumers think and act. This phase is to find out information of what products are considered as essential or self-indulgence products in consumers' perception. The focus group sample size embraces 16 consumers, one group of 8 consumers is in Hanoi, and other group is in Ho Chi Minh City. They are female decision makers or key influencers for FMCGs in a household with their ages of between 18 and 55 . The result of qualitative phase is used to develop the quantitative questionnaire.

The quantitative survey is conducted to assess consumers' purchase behavior towards overall FMCG categories, not focusing deeply on any specific category. The FMCG categories are classified as following: beverage (soft drink, energy drink, tea bag, coffee, fruit juice, package water) household care (laundry detergent, fabric softener, dishwashing liquid, tissue), personal care (hair conditioner, personal wash, body lotion, shampoo, deodorants, toothpaste, facial care products), food (cakes, gums, instant noodles, cooking oil, sauces, snakes), milk-based products (sweeten condensed milk, milk powder) and cigarette. The purchase behavior of consumers in inflation time includes consumer expenditure, lifestyle, consumption and visiting point of purchase. Ho Chi Minh City and Hanoi are chosen for the survey because they are representative for highest purchasing power in Vietnam. In every circumstance, consumers in these cities are perceived to have the fastest reactions and the trends in these cities will soon spread to other cities and beyond areas. Convenience sampling method is used. The internet access is expected to be high among the target respondents, so all questionnaires are sent to respondents via emails. In the questionnaire, a screen question is used to identify the location of respondents and their role in purchasing decision making. The questionnaire contains 4 sections, including (1) sociodemographic profile, (2) attitudinal beliefs towards market context and personal status, (3) consumption and shopping behavior pattern, (4) self-indulgence and its impact on purchase behavior and (5) intention for future purchase. Descriptive statistics are used to describe the basic features of the data in a study. Descriptive statistics provide a powerful summary that may enable comparisons across people or other units.

Table 1 describes the profile of respondents. The sample size in the quantitative phase is 360 , in which $48 \%$ of respondents is in Hanoi and 52\% is in Ho Chi Minh City. The target respondent group are decision makers and key influencers for FMCG purchase in a family. 
In the research sample, middle income followed by low income group (27\%) and respondents are majority group (47\%), high income group (26\%).

Table 1. Characteristics of the sample

\begin{tabular}{|c|c|c|}
\hline & Frequency & Percentage $(\%)$ \\
\hline \multicolumn{3}{|l|}{ Sex } \\
\hline Female & 360 & 100.0 \\
\hline Male & 0 & 0.0 \\
\hline \multicolumn{3}{|l|}{ Age } \\
\hline $18-25$ & 55 & 15.3 \\
\hline $26-35$ & 150 & 41.7 \\
\hline $36-45$ & 95 & 26.4 \\
\hline $46-55$ & 60 & 16.6 \\
\hline \multicolumn{3}{|l|}{ Occupation } \\
\hline Management & 60 & 16.7 \\
\hline Housewife & 45 & 12.5 \\
\hline Office employee & 160 & 44.4 \\
\hline Doctor/engineer & 50 & 13.9 \\
\hline Teacher & 45 & 12.5 \\
\hline \multicolumn{3}{|l|}{ Role in FMCG purchase } \\
\hline Decision maker & 220 & 61.1 \\
\hline Key influencer & 140 & 38.9 \\
\hline \multicolumn{3}{|l|}{ Household income } \\
\hline $\begin{array}{l}\text { Low income } \\
(<7 \text { Mil.VND/month) }\end{array}$ & 98 & 27.2 \\
\hline $\begin{array}{l}\text { Medium income } \\
\text { ( 7-15 Mil.VND/month) }\end{array}$ & 170 & 47.2 \\
\hline $\begin{array}{l}\text { High income } \\
\text { (>15 Mil.VND/month) }\end{array}$ & 92 & 25.6 \\
\hline \multicolumn{3}{|l|}{ Living location } \\
\hline Hanoi & 175 & 48.6 \\
\hline Ho Chi Minh City & 185 & 51.4 \\
\hline Total & 360 & 100.0 \\
\hline
\end{tabular}




\section{Research result}

Qualitative phase

The result of qualitative phase shows some differences between consumers in two markets Hanoi and Ho Chi Minh City which can be impacted by the area culture, for example the consumer concern, the promotion type they are looking for, the purchase influencing factors and activities for self-indulgence. Table 2 describes in detail the differences between two markets in terms of purchasing behavior during the inflation time.

Table 2. Result of qualitative research

\begin{tabular}{|c|c|c|}
\hline Contents & Ho Chi Minh City & Hanoi \\
\hline Top three concerns & $\begin{array}{l}\text { Commodity prices } \\
\text { Job security } \\
\text { Inflation }\end{array}$ & $\begin{array}{l}\text { Commodity prices } \\
\text { Economic crisis } \\
\text { Health }\end{array}$ \\
\hline $\begin{array}{l}\text { Change in purchase behavior } \\
\text { towards FMCGs before inflation } \\
\text { and now }\end{array}$ & $\begin{array}{l}\text { Cut down the spending. Only buy } \\
\text { what necessary } \\
\text { Nothing change. Keep the same } \\
\text { Buy more expensive products as } \\
\text { much better deals now }\end{array}$ & $\begin{array}{l}\text { Look for price promotion } \\
\text { Buy bigger pack sizes } \\
\text { Buy smaller pack sizes } \\
\text { Look for discounted } \\
\text { premium products } \\
\text { Reduce the shopping } \\
\text { frequency }\end{array}$ \\
\hline Purchase influencing factors & $\begin{array}{l}\text { Price } \\
\text { Sales promotion } \\
\text { Convenience }\end{array}$ & $\begin{array}{l}\text { Price } \\
\text { Brand } \\
\text { Sales promotion }\end{array}$ \\
\hline $\begin{array}{l}\text { Intention for FMCG purchase } \\
\text { behavior in the next 6-12 months }\end{array}$ & \multicolumn{2}{|c|}{$\begin{array}{l}\text { Still need to be cautious in spending } \\
\text { Continue to look for price discount and promotion } \\
\text { Will continue to buy if value for money }\end{array}$} \\
\hline The need of self-indulgence & $\begin{array}{l}\text { Of course, everyone needs to } \\
\text { learn to enjoy life } \\
\text { Many pressure in life. Always } \\
\text { need to do something to self- } \\
\text { motivate. }\end{array}$ & $\begin{array}{l}\text { Expectation for life changes } \\
\text { now. More demands to } \\
\text { enjoy life. } \\
\text { Always need to keep myself } \\
\text { if happy to be able to } \\
\text { overcome the challenges. }\end{array}$ \\
\hline Activities for self-indulgence & $\begin{array}{l}\text { Buy something for myself (i.e. } \\
\text { clothes, cosmetics) } \\
\text { Do out of home activities (i.e. } \\
\text { cinema) } \\
\text { Travelling } \\
\text { Go to beauty services }\end{array}$ & $\begin{array}{l}\text { Buy something for myself } \\
\text { (i.e. clothes, cosmetics) } \\
\text { Gathering with my friends } \\
\text { Read a book/Watch movies } \\
\text { with my family } \\
\text { Go to beauty services }\end{array}$ \\
\hline $\begin{array}{l}\text { Products to buy for self- } \\
\text { indulgence }\end{array}$ & $\begin{array}{l}\text { Shoes } \\
\text { Clothes } \\
\text { Handbag } \\
\text { Cosmetics } \\
\text { Skincare products } \\
\text { Perfume }\end{array}$ & $\begin{array}{l}\text { Handbag } \\
\text { Clothes } \\
\text { Cosmetics } \\
\text { Shoes } \\
\text { Skincare products } \\
\text { Perfume }\end{array}$ \\
\hline
\end{tabular}


The qualitative research result shows that consumers cut down spending un-necessary products. While Ho Chi Minh consumers look for products with sales promotion and buy private brand products, Hanoi consumers look for discount premium products and reduce the frequency of shopping. However, consumers think that under pressure in life, they need to do something to selfmotivate. They need to keep themselves happy to be able to overcome challenges in their life. So activities for self-indulgence may make their feeling better. These activities comprise of buying something for themselves, go to cinema, eating out with their family and friends, traveling somewhere and go to beauty shops. The products they often buy for self-indulgence include cosmetics, skin care products, perfume, shoes, clothes, and handbags. The most factors influence consumers buying decision are price and promotion. Their buying tendency in the next year is to be cautious in spending, continue to look for price discount and sales promotion and buy if value for money.

\section{Quantitative phase}

\section{Main concerns during the inflation time}

Given the current attitudinal beliefs, the consumers express several concerns for themselves in the next six months as shown in Table 3. Economy status and price increase are identified as the top concerns in consumers' perception. Such concerns will directly impact to their purchase intention in the present and in the future.

Table 3. The top concerns in the next 6 months

\begin{tabular}{|l|c|c|c|c|c|}
\hline $\begin{array}{l}\text { Concern } \\
\mathbf{n}=\mathbf{3 6 0}\end{array}$ & $\mathbf{1}^{\text {st }} \mathbf{R a n k}$ & $\mathbf{2}^{\text {nd }} \mathbf{R a n k}$ & $\mathbf{3}^{\text {rd }} \mathbf{R a n k}$ & $\mathbf{4}^{\text {th }} \mathbf{R a n k}$ & $\mathbf{5}^{\text {th }} \mathbf{R a n k}$ \\
\hline Economy status & $27 \%$ & $20 \%$ & $28 \%$ & $18 \%$ & $7 \%$ \\
\hline Price increase in utility bill & $25 \%$ & $25 \%$ & $25 \%$ & $12 \%$ & $13 \%$ \\
\hline Food price increase & $23 \%$ & $23 \%$ & $25 \%$ & $15 \%$ & $14 \%$ \\
\hline Job security & $15 \%$ & $17 \%$ & $13 \%$ & $25 \%$ & $30 \%$ \\
\hline Health & $10 \%$ & $15 \%$ & $9 \%$ & $30 \%$ & $36 \%$ \\
\hline
\end{tabular}

The majority of consumers (70\%) have reacted to the tough economic and personal finance status via cutting down on their FMCG spending and the reaction happened very early right after the market showed the sign of inflation and uncertainty in 2011-2012.

\section{Cutting down spending FMCGs}

The overall cut down level for FMCG spending is about $16 \%$ as per indicated in the Figure 2. Faster response to the inflation but the level of cutting down of
Hanoi consumers is lower than Ho Chi Minh consumers (11\% vs. 17\%). Most of respondents mentioned that they cut down on FMCG spending because things were more expensive and their family had less money to spend. Also, the future outlook in their perception is not bright enough to trigger them to purchase more. The respondents admitted that they were afraid the economy would get worse in the next year and then, 36\% of respondents said they had to save more and be more cautious in spending. 
Figure 2. The cutting down spending FMCGs

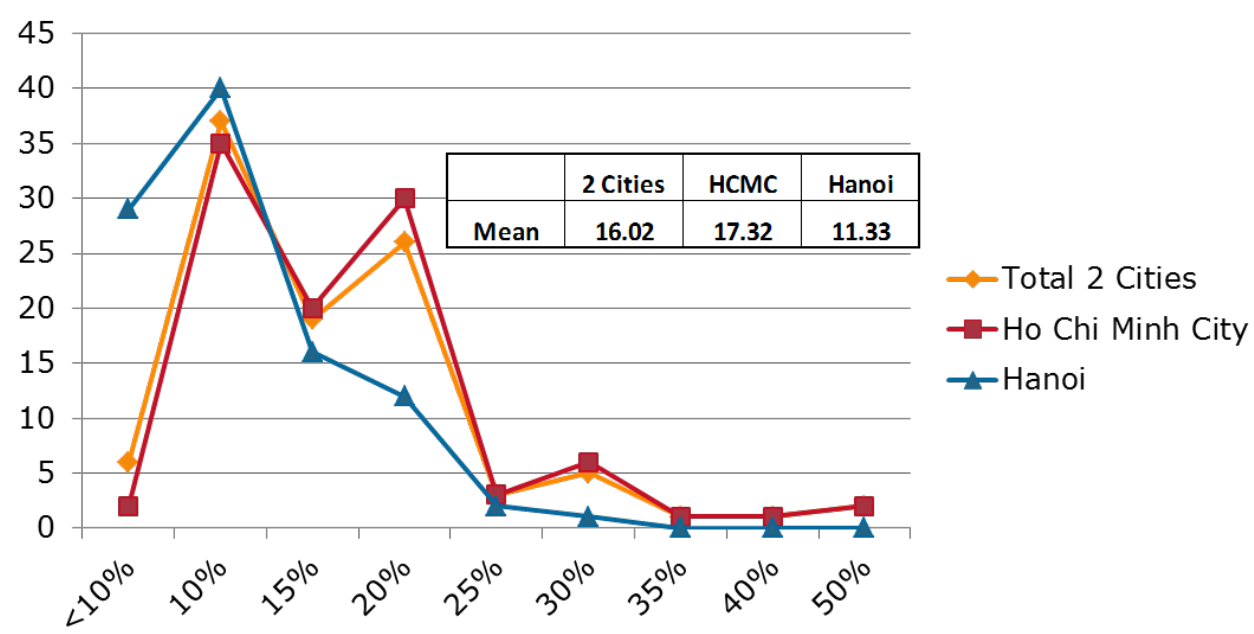

Figure 3 notes that Hanoi consumers mentioned that they already cut down on seem to have a faster reaction towards the spending 12 months ago while the timing the situation compared to Ho Chi Minh in Ho Chi Minh City was spread from 12 consumers when $52 \%$ of respondents months ago (36\%) to 9 months ago (53\%).

Figure 3. The time to start cutting down on FMCG spending

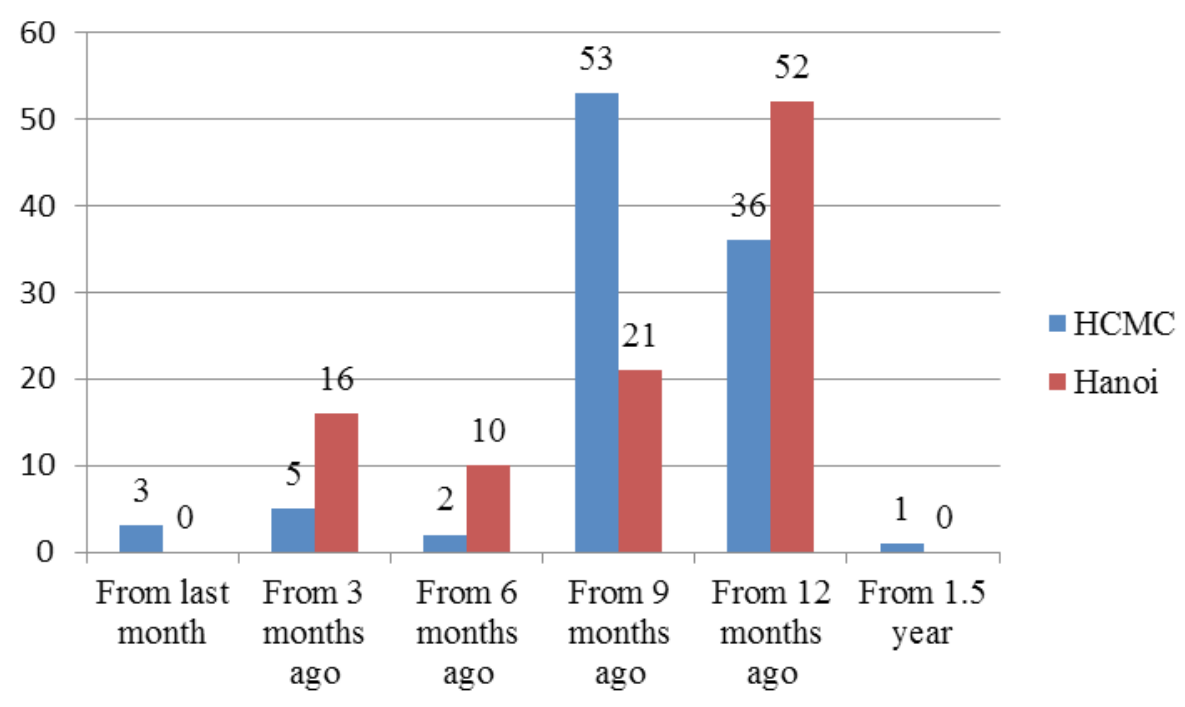

FMCG consumption and shopping 15\%, 14\% of respondents respectively. A

\section{behavior pattern}

Dropping the 'non-essentials' is the common action from one-third of the respondents. Being more promotion junkie or looking for better saving with bigger packs or trading down to cheaper products are chosen to be the next options with 19\%, little different choice set is seen between Ho Chi Minh and Hanoi consumers. Hanoi consumers prefer looking for local or Vietnamese brands as the solution (19\%) while Ho Chi Minh consumers trade down to cheaper products without a real care about the product brand or origin (23\%). 
Figure 4. The change in FMCG purchase behavior compared with the previous time

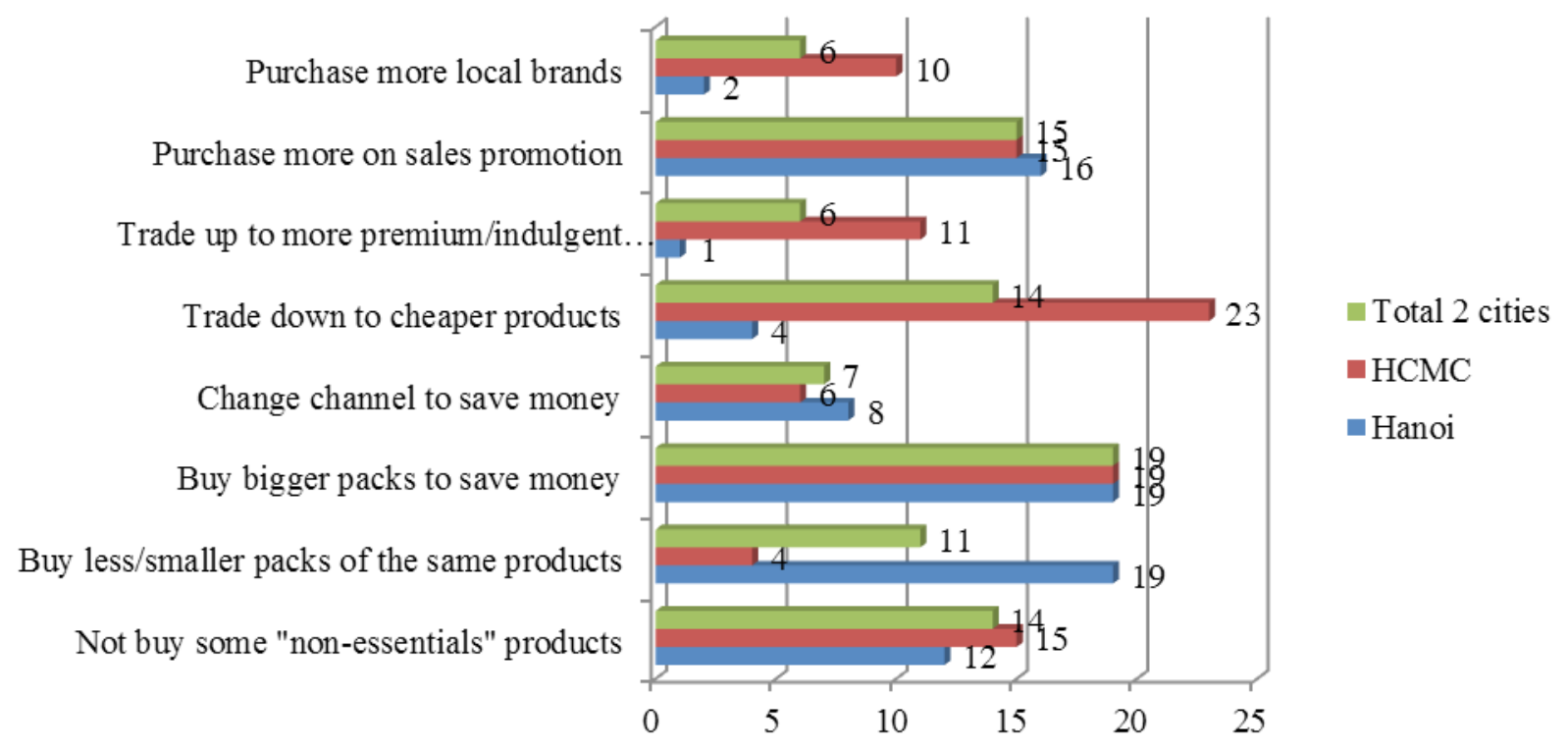

The change in FMCG purchase in category for children like milk powder behavior is seen across the product (43\% of respondents still consume the same groups (personal care products, household amount without any change) and change care products, food and beverage). The happens in other categories for family consumption behavior differs among like cooking oil, shampoo, detergent as in categories when there is minimum change Table 4.

Table 4. The change in consumption behavior among some key categories

\begin{tabular}{|l|l|l|l|l|l|l|}
\hline Consumption behavior (\%) & $\begin{array}{l}\text { Milk } \\
\text { powder }\end{array}$ & Biscuit & & $\begin{array}{l}\text { Soft } \\
\text { drink }\end{array}$ & & Laundry \\
\hline Consume more & 0 & 0 & 1 & 0 & 3 & 1 \\
\hline Consume less & 7 & 88 & 70 & 49 & 18 & 13 \\
\hline $\begin{array}{l}\text { Consume the same amount but } \\
\text { look for better saving }\end{array}$ & 50 & 12 & 29 & 48 & 79 & 89 \\
\hline $\begin{array}{l}\text { Consume the same amount } \\
\text { without any change }\end{array}$ & 43 & 0 & 0 & 3 & 0 & 0 \\
\hline
\end{tabular}

However, the good point is same amount but look for better saving consumers tend to look for a better saving while only $18 \%$ claim to consume less for in consumption rather than consume less shampoo category. This is definitely a source for most of the categories. For example, of continuous growth for consumption in $79 \%$ of respondents claim to consumer the Vietnam market in the future. 
Table 5. The change in shopping behavior

\begin{tabular}{|l|r|r|r|}
\hline \multicolumn{1}{|c|}{ Changing behavior (\%) } & $\begin{array}{c}\text { Totally } \\
\text { Average } \\
(\mathbf{n = 3 6 0})\end{array}$ & $\begin{array}{c}\text { HCMC } \\
(\mathbf{n}=\mathbf{1 8 5})\end{array}$ & $\begin{array}{c}\text { Hanoi } \\
(\mathbf{n}=\mathbf{1 7 5})\end{array}$ \\
\hline Reduce the number of visiting shops & 59 & 60 & 58 \\
\hline $\begin{array}{l}\text { Choose the shops where there are cheaper prices regardless the } \\
\text { distance of travel }\end{array}$ & 9 & 7 & 14 \\
\hline Visit shops/ grocery stores near home to save cost on petrol & 33 & 31 & 36 \\
\hline Reduce number of products per purchase & 44 & 40 & 52 \\
\hline Choose to buy more products on promotion & 51 & 49 & 54 \\
\hline Buy more Vietnamese goods & 26 & 22 & 35 \\
\hline
\end{tabular}

There are also some changes in indulgence. The need of making selfshopping behavior identified via the happy is very high among all respondents study. Table 5 shows that nearly $60 \%$ with the mean of 4.05 with the scale from of respondents reduced the number of 1 (strongly disagree) to 5 (strongly agree). visiting shops and $44 \%$ of respondents They have a strong belief that they can reduced number of products per purchase. only make the others happy when they They also choose the nearer stores to save are happy themselves $($ mean $=4.13)$. And petrol $(33 \%)$ and bought more products on the mean to satisfy the self-indulgence promotion (44\%).

Self-indulgence and its impact on purchase behavior via buying something new but affordable during the inflation is commonly shared among the majority of respondents (mean

Figure 5 presents the needs of self- $=3.58$ ).

\section{Figure 5. Assessment of self-indulgence needs}

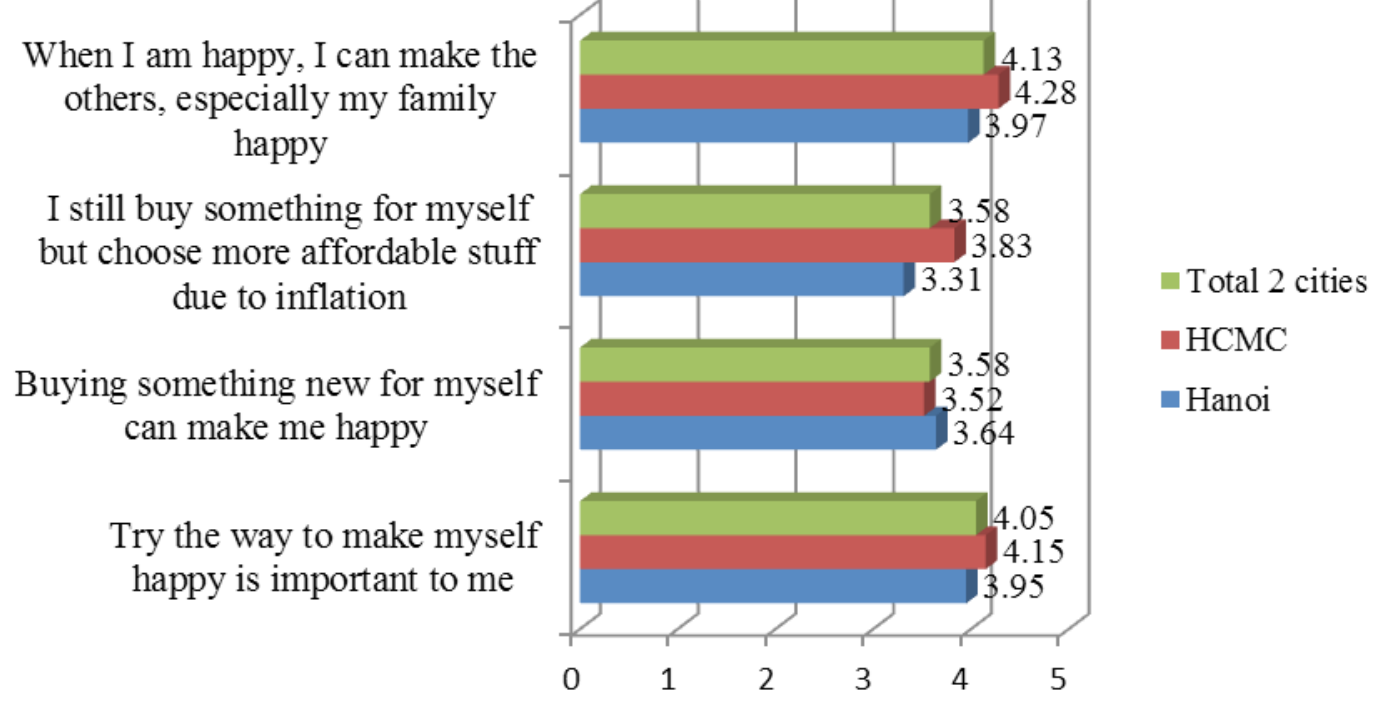




\section{Intention for future FMCG purchase}

The future is not really bright in respondents' opinions with two-third of them said that they did not believe the inflation would end in the next 6 months (see Table 6).
Given such perception towards future outlook, the consumers tend to continue the 'saving' approach with purchase more on promotion $(24 \%)$ and not buy some 'non-essentials' $(21 \%)$. Understanding all the possible purchase intentions is critical to the manufacturers to define the right marketing strategy.

Table 6. The future intention for FMCG purchase in the next 6 months

\begin{tabular}{|l|l|l|l|}
\hline \multicolumn{1}{|c|}{ Future intention (\%) } & $\begin{array}{l}\text { Totally } \\
\text { Average } \\
(\mathbf{n}=\mathbf{3 6 0})\end{array}$ & $\begin{array}{l}\text { HCMC } \\
(\mathbf{n}=\mathbf{1 8 5})\end{array}$ & $\begin{array}{l}\text { Hanoi } \\
(\mathbf{n}=\mathbf{1 7 5})\end{array}$ \\
\hline Not buy some 'non-essentials' & 21 & 19 & 23 \\
\hline Buy less / smaller packs of the same products & 4 & 5 & 3 \\
\hline Buy bigger packs to save money & 14 & 11 & 18 \\
\hline Change channel to save money & 9 & 13 & 4 \\
\hline Trade down to cheaper products & 8 & 12 & 4 \\
\hline Trade up to more premium/indulgent products & 10 & 9 & 12 \\
\hline Purchase more on promotion & 24 & 24 & 25 \\
\hline Purchase more local brands & 7 & 4 & 11 \\
\hline No change & 2 & 2 & 0 \\
\hline
\end{tabular}

\section{Conclusion and managerial implication}

The overall objective of this paper is to understand the consumer behavior during inflation time. The qualitative and quantitative researches were used to answer the four research questions.

The first question is to understand the change in consumer behavior towards FMCG purchase during inflation under the question that "During the inflation time, do consumers cut down their spending on what they perceive un-necessaries?". The result suggests that the consumers are very aware of the overall economic status and that directly impacts to their FMCG purchase behavior. They admit to have cut down on their overall spending, especially for non-essentials products. What consumers perceived in terms of the economic context and their personal or household financial status did impact on their actual behavior.
The second question is "Are consumers more active in seeking for better saving choice such as products on promotion, cheaper brands, smaller pack sizes, etc.?". The result shows a significant percentage of respondents did have a change in their FMCG purchase behavior. The overall theme for the change was to look for a better saving in FMCG spending via better deals by purchasing more on promotion, better average price spent by purchasing bigger pack sizes, compromising the brands to pay less by buying cheaper brands or buying local brand or change the channel to save. However, there are some differences in choice between Ho Chi Minh consumers and Hanoi consumers. While consumers in both markets share the common behavior of purchasing more on promotion and buying bigger pack sizes to save, they are different in the brand consciousness and 
channel choice. Ho Chi Minh consumers are open to trade down to cheaper brands while Hanoi consumers still look for a branded one although that is a Vietnamese brand. This truly reflects a characteristic of Hanoi people which appear consciousness and branded-towards preference when Ho Chi Minh people more care about the functionality and more practical in spending and consumption.

The third question is to explore the impact of the need of self-indulgence on the purchase behavior: "Along with the getting more sophisticated consumer demand, whether consumers head to affordable premium and/ or self-indulgence products or not". In the qualitative phase, consumers shared the high need of being happy and self-indulgent. They are getting more and more demanding in life and require more activities to motivate themselves. Buying new things such as clothes, cosmetics, handbags, etc. is chosen as a basic selfindulgence activity. In the quantitative phase, this finding is confirmed again that the need of being happy is increasing and buying a new thing is an option to consumers. However, during the inflation time, they need to balance between the need and the capability. They are looking for more affordable things, as it is noted that consumers cut down in their spending for non-essentials. At the same time, however, they still have the increasing need of selfindulgence and that encourages them to continue buying new and affordable things to satisfy the need such as lipsticks, shoes, etc.

The answer of the fourth question is to get some ideas of the potential future consumption trends when understand the consumers' perceptions towards future context and how they tend to behave. The majority of the respondents $(68 \%)$ did not have a strong belief that the inflation would end within the next six months and they would continue the 'best deal strategy'.
Therefore, the potential consumption trends are forecasted in the next future as below:

Belt bucking trend: This trend will continue due to the overall not very positive outlook. Consumers will keep being very cautious with un-necessities spending.

Value seeker trend: Consumers will keep seeking for value in all the purchases. The value here is not necessarily the low price but can be price/benefit combination that consumers can reckon. Consumers will continue looking for either small packs (for low and middle income households) or big packs (for high income households). They will browse and compare among the channels and brands to make sure that they will get the best deals for all the purchases. Consumers will become promotion junkies.

Affordable ppremium trend: The more consumers are connected, the higher need for new experiment is. As long as the premium products can prove to provide consumers with unique benefits which can be either functional or emotional benefits and within the reach pricing point. There is still a big opportunity for such products to grow.

It is obviously reckoned that consumers do observe and follow closely the movement in the macro status. They have quick reactions to what they perceive. The majority of respondents have cut down their spending since 12 months ago, right when the inflation was picking up. Therefore, the manufacturers need to keep close and continuous connection with consumers to be updated with all the changes in consumption potential to have a better sales and production forecasting.

For the pack size offer, manufacturers need to pay attention to the fact that a group of consumers will tend to buy smaller pack sizes to cope with the price increase while another group of consumers 
will buy bigger pack sizes to have a better saving per unit. The pack size range offer should be developed accordingly to meet such demands. For the brand offer, there are opportunities for both mainstream and premium brands to be successful during this time. However, the brand needs to be able to provide reason to believe or clear benefits to consumers for them to be willing to buy. For the innovation offer, health consciousness or self-indulgence, products for kids are increasing trends that are worthwhile considering new products to meet.

Manufacturers suffer from the input cost increase which leads to the requirement to pass on the price increase to consumers. However, they should be very aware that consumers are browsing more and more and they are on top of the price gaps among products. Strategic value proposition planning is necessary to harness different segments via packaging, positioning and optimal pricing for consumers. During the inflation time, while consumers tend to cut down on shopping frequency or try to save on transportation cost, being available in the nearby stores means everything.

While price and promotion factors are their top of mind, Ho Chi Minh consumers also care about convenience while Hanoi consumers care about health and brand. Ho Chi Minh consumers are willing to trade down to cheaper brands if they cannot afford the currently used brand. Therefore, promoting for value brand or smaller pack size and ensure the wide availability are critical to keep the consumers with the brands. For Hanoi consumers, the manufacturers should promote more and communicate more to consumers regarding health and brand and quality of the products.

While consumers become more of promotion junkies and in-store competition becomes fiercer, both consumer and trade promotions will be leveraged at the most by the manufacturers. However, there is a big side effect for a frequent and price discountbased promotion scheme. Manufacturers need to communicate to consumers of the value and benefits that their products offer to create the differentiation. Manufacturers can harness the explosive combination of right media and content to engage specific target audience continuously.

\section{Limitation and further research}

The paper demonstrates a research conducted in Ho Chi Minh City and Hanoi only. The convenience sampling method with 360 respondents may not be representative for all Vietnamese consumers which limit the generalization of the research. Future study should extend larger sample in other regions, especially the rural market to better understand the difference of purchase behavior between urban and rural consumers. 


\section{REFERENCES}

CIA World Factbook (2012), Vietnam inflation rate (consumer price index), https:// www.cia.gov/library/publications/the-world-factbook/, accessed on 10/9/2012

Nielsen Vietnam (2011), Pricing Analytics Study, http://www.nielsen.com/intl/vn/newsinsights/reports.html, accessed on 11/10/2012

Nielsen Vietnam (2012), Global Consumer Confidence Study, http://www.nielsen.com/ intl/vn/news-insights/reports.html, accessed on 11/10/2012

Vietnam General Statistics Office (2012), Consumer price index of whole country, http://www.gso.gov.vn/default_en.aspx?tabid=462\&idmid=2,2\&ItemID=12578, accessed on $11 / 9 / 2012$ 